\title{
Research on the construction strategy of double-qualified team in vocational education colleges
}

\author{
Lei Qiu ${ }^{1, a,{ }^{*}}$, Xuezhi Zhang ${ }^{2, \mathrm{~b}}$ and Dawei $\mathrm{Hao}^{3, \mathrm{c}}$ \\ 123 Ordnance NCO Academy, Army Engineering University of PLA, Wuhan 430075, Hubei, China \\ a175823704@qq.coml, b5937527@qq.com, c33736483@qq.com
}

Keywords: "double-qualified" teachers, Vocational education, Strategy.

\begin{abstract}
The realization of talent training objectives in vocational education colleges is inseparable from the support of the construction of "double-qualified" teachers. Colleges should strengthen the cultivation of "double-qualified" teachers in the construction of teaching staff, make full efforts in top-level design, broaden training channels, introduce competition mechanism, carry out university-enterprise exchanges, consolidate innovative ideas, and insist on talent introduction. Take innovation as the driving force, constantly improve the evaluation mechanism, promote teachers to improve their personal ability, and build a "double-qualified" teacher team with high quality and strong skills.
\end{abstract}

\section{Introduction}

The teaching goal of vocational education is to cultivate talents who meet the needs of various fields of society, and the teaching quality is directly related to the future development of enterprises. If we want to promote the sustainable development of vocational education colleges, we must optimize the resources of teachers. The construction of teaching quality system should be integrated with the cultivation of compound talents, and it is an inevitable trend to build a qualified double-qualified teacher team.

At present, there is no unified standard for double-qualified teachers, but it is generally believed that double-qualified teachers should have the following characteristics: first, teachers should have both teacher qualification certificates and vocational skills certificates. Second, have the professional quality of both teachers and technicians. Third, both lecturer title and engineers titles. Fourth, we should have rich professional knowledge and solid professional skills.

\section{The goal of vocational education personnel training needs to build "double-qualified" teachers}

Generally speaking, talents are divided into two types, one is academic, the other is applied. Applied talents can be divided into three types according to their different job connotation and tasks, namely, engineering talents, technical talents and skilled talents. As for vocational education, it is to cultivate skilled talents who can serve the society and enterprises. This requires vocational education must let students learn theoretical knowledge at the same time, to learn the actual operation of front-line technical personnel, graduation can be hands-on operation. For teachers in vocational colleges and universities, they cannot teach qualified students without practical operation ability. It is imperative for vocational colleges to build a "double-qualified" teacher team for the sustainable development of vocational education, no matter from the analysis of foreign successful vocational education experience or the goal of talent training. Teachers must understand the basic principles of vocational education, master the professional theoretical knowledge, and have the ability to use the theoretical knowledge to solve relevant practical problems. 


\section{The strategy of "double qualified" teacher team construction}

\subsection{Do a good job in top-level design, attach importance to the overall construction plan of "double-qualified" teachers}

In order to achieve the goal of talent cultivation, vocational colleges need to do a good job in top-level design, including the training of "double-qualified" teachers into the key work of the construction of the teaching staff, from the formulation of incentive policies, evaluation and assessment to the provision of training opportunities and conditions for teachers and other aspects to ensure that the training of "double-qualified" teachers can be implemented.

At present, the evaluation system of theoretical teaching quality in vocational colleges is quite complete, while the evaluation mechanism of practical teaching is not perfect or even absent. If the assessment system does not involve practical teaching contents, then teachers will not pay attention to practical teaching links and simply complete the practical teaching workload, making it difficult to truly achieve the goal of talent cultivation. Therefore, vocational colleges must encourage teachers to carry out various forms of practical teaching, improve the evaluation system and standards of practical teaching, strengthen the assessment of practical teaching, and form a complete, feasible and reasonable evaluation system of practical teaching quality, and link the evaluation results with the professional title review, post change and year-end assessment of teachers. The establishment of a "double-qualified" teacher evaluation system that focuses on work performance, focuses on professional ability, and attaches equal importance to professional ethics and professional skills assessment, so that teachers have the pressure to improve their practical teaching level and the motivation to improve their practical operation skills. To formulate a plan for the overall construction of the teaching staff, so as to make the training of professional teachers more systematic and regular. We will make teacher development an important priority, and establish a flexible, diversified, open and well-structured teacher training system.

\subsection{Broaden the training channels and strengthen the construction of "double-qualified" teachers}

"Double-qualified" teachers should have social practice experience, good communication, organization and coordination ability, rich theory and solid professional application ability. Therefore, in strengthening the construction of "double-qualified" teachers, colleges and universities should pay more attention to "internal training" and "external introduction". Hire engineers or technical experts to teach students. Teachers are required to constantly enrich and update their own practical experience on the basis of mastering professional knowledge and skills, so as to improve their own "double quality", and provide more reform ideas for professional reform, curriculum reconstruction and personnel training program revision.

\subsection{Provide competition mechanism and enhance the vitality of "double-qualified" teachers}

Vocational colleges should make use of such advantageous resources as school-enterprise cooperation and off-campus internship to provide teachers with front-line practice conditions. Meanwhile, a competition mechanism is introduced to encourage teachers to participate in national or provincial teacher training and special competitions at all levels, so as to improve teachers' abilities.

\subsection{Carry out cooperation and exchanges to improve the practical experience of "double-qualified" teachers}

In the protection of schools and enterprises under the premise of mutual interests, give full play to the role of the enterprise, make teachers a line in the enterprise to improve their practical experience, realize the combination of theory and practice. Teachers can participate in practice according to their own teaching expertise and cultivate their own professional skills. Of course, they can also choose some positions for "cross-border experience" according to their own interests. Teachers can take the following ways to participate in practice. 
3.4.1 Temporary type: The enterprise gives the specialized teacher to arrange a post, completes the corresponding work task, the exercise time at least six months above. In addition to doing their job well, teachers can also participate in enterprise project research, and carry out training for enterprise employees, exchange and learn from each other.

3.4.2 A part-time job: Some vocational college teaching task is heavier, the teacher cannot take off guard practice, can use part-time job means, namely below the circumstance that does not affect normal teaching job, be engaged in part-time job to the enterprise.

3.4.3 Short-term training: Teachers are arranged to work in cooperative enterprises for a period of time in the summer and winter holidays, so that teachers can understand the quality and ability matched by enterprise development and post, and learn advanced management methods and concepts of the industry.

\subsection{Tamp innovative ideas, timely update the "double teacher" thinking cognition}

Innovative thinking means to creatively propose unique solutions to problems on the basis of existing knowledge and experience. Innovative thinking is not limited to the inherent concepts and ways of thinking, and can break through the limitations of conformity psychology, which is an important standard to measure excellent talents.

Colleges and universities should reinforce innovative ideas, encourage teachers to carry out in-depth learning and research activities, determine the scientific research direction from the needs of enterprises and conduct in-depth analysis, so as to improve the policy of scientific research task evaluation in schools. Such as raising the proportion of industry-university-research projects, revising the reward and punishment system, stimulating the enthusiasm of all parties to participate in cooperation, so that teachers can achieve the real "double quality".

\subsection{Increase the introduction of "double-qualified" teachers and promote the communication of teachers' teams}

In order to improve the proportion of "double-qualified" teachers and optimize the structure of "double-qualified" teachers, the sources of teachers must be diversified. We should actively introduce experts with higher educational levels who understand both theory and practice to serve as part-time teachers. Establish and improve the management mechanism of part-time teachers, create a good learning and working environment for them, and promote the close combination of theoretical teaching and practical teaching. Vocational colleges and universities with conditions can actively introduce overseas students or foreign teachers to learn foreign vocational education methods and ideas, promote teaching reform and improve teachers' teaching level.

\section{Evaluation index of "double-qualified" teacher team construction}

The establishment of evaluation index is a long process which needs to be accumulated continuously. In determining the evaluation indexes, it is necessary to classify and screen all the initially obtained indexes to ensure that the evaluation indexes are highly targeted and feasible. If it is too high, teachers will think that the requirements are too high, and all efforts cannot be achieved, and the indicators will not play an incentive role; If it is too low, teachers can reach it easily, and the evaluation index has lost its incentive function. Generally speaking, the evaluation index of "double-qualified" teacher team construction can be divided into the structure index, process index and result index.

\subsection{Structural index}

Mainly for age, education, professional and technical grades and titles.

\subsection{Process index}

4.2.1 Evaluation indexes of training methods: Involve specific evaluation indexes such as lecture series (pedagogy, psychology, scientific research, professional technology), teaching observation, trial lecture, training class hours, examination, enterprise practice time, etc. 
4.2.2 Professional quality evaluation indexes: Involved in professional ethics (to the students' professional ethics, professional ethics of colleagues, for industry practitioners of professional ethics, professional belief, professional knowledge, professional emotion, professional perseverance), professional attitude, service consciousness, serious and responsible, ethical), vocational guidance, help students career planning, develop students employment ability, help students understand workplace culture, help students balance work world multiple roles), social ability, communication and coordination, division of labor cooperation).

4.2.3 Evaluation index of professional practice level: It involves professional knowledge, research ability and management ability.

4.2.4 Teaching ability evaluation indexes: It involves expression ability, teaching means, stimulating interest, linking theory with practice, innovation consciousness, classroom management, self-evaluation, student evaluation, constructive feedback and so on.

\subsection{Outcome index}

\subsubsection{Resources: Student/teacher ratio.}

4.3.2 Teaching ability: Responsible for the number of courses, teaching hours, online and offline courses, information course construction, guiding students to win awards, teachers to win awards, etc.

4.3.3 International influence: Full-time teachers go abroad to guide and conduct training time, the number of full-time teachers who hold positions in foreign countries, and the number of professional teaching standards and curriculum standards approved by foreign countries.

4.3.4 Service contribution: Number of awards in foreign skills competition, horizontal technical service to amount, vertical scientific research fund to amount, technology transaction to amount, non-academic training to amount, public welfare training service, etc.

\section{Conclusion}

With the rapid development of vocational education in China, the teaching force of vocational colleges and universities has been significantly improved compared with the past, but there are still many problems in general, such as putting more emphasis on theory than practice, imperfect training mode and difficult to improve the training speed. Therefore, it is the key to improve the quality of teaching and the level of talent cultivation in vocational colleges to build a "double-qualified" teacher team with high quality and strong skills. Through the establishment of evaluation indexes, the teaching team of "double-teacher structure" can adjust and modify the indexes appropriately according to the changes of internal and external environment, and further improve and adjust the evaluation indexes, so as to achieve the goal of cultivating high-quality talents.

\section{References}

[1] Ji-dong Tao, New understanding of the connotation of "double-teacher" professional teaching team, Vocational and technical education, 2011,32 (22) : 49-52.

[2] Chen bo, Discussion on the construction approach of "double-teacher" structural teaching team, Journal of hunan institute of industry and technology, 2011,11 (6) : 90-91.

[3] De-qiang Liu, Design of performance assessment indicator model of teaching team based on KPI "double-teacher structure", Education and careers, 2011(33) : 79-81.

[4] Dan li, Research on the construction of "double-qualified" teachers under the background of industry-education integration. Frontier, 2018 (5): 39-45. 